\title{
PENGARUH STRES DAN KONFLIK KERJA TERHADAP KUALITAS KERJA KARYAWAN DI PUSKESMAS GEDONG TATAAN
}

\author{
Novita Sari, Vonny Tiara Narundana \\ Fakultas Ekonomi dan Binis Universitas Bandar Lampung \\ Jl. ZA. Pagar Alam No. 26 Labuhan Ratu, Kedaton 35142 \\ Bandar Lampung, Indonesia \\ Email: \\ Novita.16011051@student.ubl.ac.id, vonny.tiara@.ubl.ac.id
}

\begin{abstract}
ABSTRAK
Banyak faktor yang mempengaruhi tinggi rendahnya kualitas kerja karyawan Puskesmas dalam memberikan pelayanan kesehatan kepada masyarakat. Salah satu di antaranya adalah tekanan akibat pekerjaan (stres) dan kemampuan karyawan dalam mengelola konflik kerja. Rumusan masalah dalam penelitian ini adalah apakah stres dan konflik kerja berpengaruh secara parsial dan simultan terhadap kualitas kerja karyawan di Puskesmas Gedong Tataan. Metode analisis yang digunakan yaitu analisis kualitatif menggunakan metode tabulasi dan analisis kuantitaf menggunakan alat analisis analisis regresi linier berganda. Hasil kesimpulan menunjukkan bahwa stres $\left(\mathrm{X}_{1}\right)$ berpengaruh terhadap kualitas kerja karyawan $(\mathrm{Y})$ di Puskesmas Gedong Tataan. Kemudian konflik kerja $\left(\mathrm{X}_{2}\right)$ berpengaruh terhadap kualitas kerja karyawan (Y) di Puskesmas Gedong Tataan dan stres $\left(\mathrm{X}_{1}\right)$ dan konflik kerja $\left(\mathrm{X}_{2}\right)$ berpengaruh terhadap kualitas kerja karyawan (Y) di Puskesmas Gedong Tataan.
\end{abstract}

Kata Kunci : Stres, Konflik Kerja, Kualitas Kerja, Puskesmas Gedong Tataan.

\begin{abstract}
Many factors influence the level of work quality of Puskesmas employees in providing health services to the community. One of them is work-related stress (stress) and the ability of employees to manage work conflicts. The formulation of the problem in this study is whether stress and work conflict have a partial and simultaneous effect on the quality of work of employees at the Gedong Tataan Health Center. The analytical method used is qualitative analysis using the tabulation method and quantitative analysis using multiple linear regression analysis analysis tools. The conclusion shows that stress (XI) influences the quality of work of employees (Y) in the Gedong Tataan Health Center. Then work conflict (X2) affects the work quality of employees (Y) in Gedong Tataan Health Center and stress (X1) and work conflict (X2) affect the work quality of employees (Y) in Gedong Tataan Health Center.
\end{abstract}

Keywords: Stress, Work Conflict, Work Quality, Gedong Tataan Health Center. 


\section{PENDAHULUAN}

\section{Latar Belakang}

Pusat Kesehatan Masyarakat (Puskesmas) merupakan kesatuan organisasi fungsional yang menyelenggarakan upaya kesehatan yang bersifat menyeluruh, terpadu, merata dapat diterima dan terjangkau oleh masyarakat dengan peran serta aktif masyarakat dan menggunakan hasil pengembangan ilmu pengetahuan dan teknologi tepat guna, dengan biaya yang dapat dipikul oleh pemerintah dan masyarakat luas guna mencapai derajat kesehatan yang optimal, tanpa mengabaikan mutu pelayanan kepada perorangan kepada masyarakat.

Peranan dan kedudukan Puskesmas adalah sebagai ujung tombak sistem pelayanan kesehatan di Indonesia. Sebagai sarana pelayanan kesehatan terdepan di Indonesia, maka Puskesmas bertanggung jawab dalam menyelenggarakan pelayartan kesehatan masyarakat, juga bertanggung jawab dalam menyelenggarakan pelayanan kedokteran. Selanjutnya fungsi Puskesmas adalah dapat bertindak sebagai motivator, fasilitator dan turut serta memantau terselenggaranya proses pembangunan agar berdampak positif terhadap kesehatan masyarakat di wilayah kerjanya. Hasil yang diharapkan dalam menjalankan fungsi ini antara lain adalah terselenggaranya pembangunan di bidang kesehatan yang mendukung terciptanya lingkungan dan perilaku sehat.

Sebagai ujung tombak pelayanan dan pembangunan kesehatan di Indonesia, maka Puskesmas perlu mendapatkan perhatian terutama berkaitan dengan kualitas pelayanan kesehatan puskesmas sehingga dalam hal ini puskesmas dituntut untuk selalu meningkatkan profesionalisasi dari para pegawainya serta meningkatkan fasilitas atau sarana kesehatannya untuk memberikan kepuasan kepada masyarakat pengguna jasa layanan kesehatan.

Puskesmas Gedong Tataan, Kabupaten Pesawaran merupakan salah satu dari sekian banyak puskesmas yang dalam pelaksanaanya ikut berpartisipasi melaksanakan pelayanan dan pembangunan kesehatan kepada masyarakat. Sayangnya dalam penyelenggaraan pelayanan kesehatan kepada masyarakat di Kecamatan Gedong Tataan masih belum memenuhi harapan masyarakat di Kecamatan Gedong Tataan. Banyak keluhan masyarakat terhadap pelayanan Puskesmas Gedong Tataan yang tidak memberikan pelayanan yang baik kepada masyarakat yang membutuhkan pelayanan kesehatan.

Upaya untuk menjadikan sumber daya manusia di Puskesmas Gedong Tataan memiliki kualitas yang baik maka Kepala Puskesmas harus mampu menjaga lingkungan kerja di Puskesmas Gedong Tataan senantiasa harmonis dan kondusif sehingga setiap pegawai mau untuk berkontribusi dalam memberikan pelayanan di bidang kesehatan secara maksimal.

Melalui lingkungan kerja yang harmonis dan kondusif ini maka setiap pegawai dapat meminimalisir tekanan (stres) dalam pelaksanaan pekerjaan serta meminimalisir terjadinya konflik baik konflik antara setiap individu dengan tanggung jawab pekerjaannya maupun konflik di antara pegawai. Apabila setiap pegawai maupun Kepala Puskesmas tidak mampu mengelola adanya stres dan konflik kerja, maka hal ini akan berakibat dengan menurunnya kualitas kerja pegawai di Puskesmas Gedong Tataan.

Berdasarkan hasil pengamatan awal yang dilakukan, masalah stres kerja yang ada di Puskesmas Gedong Tataan adalah beban 
dan tuntutan pekerjaan yang relatif tinggi dalam memberikan layanan kesehatan kepada masyarakat, sementara tuntutan dan harapan masyarakat akan layanan kesehatan yang baik dan maksimal. Tuntutan ini tentunya sedikit banyak dapat mengganggu hubungan kerja di antara pegawai sehingga terjadi konflik, misalnya saling menyalahkan satu sama lain dan adanya ketergantungan terhadap rekan kerja. Di samping itu juga, karena sebagian besar pegawai adalah perempuan yang sudah berkeluarga, menyebabkan terjadinya benturan antara kepentingan keluarga dan pekerjaan terutama dari sisi waktu bekerja yang kadang lebih dari jam yang semestinya.

Pemberian pelayanan kepada masyarakat merupakan salah satu perwujudan dari fungsi aparatur negara sebagai abdi masyarakat. Namun realita menunjukkan bahwa kondisi penyelenggaraan pelayanan publik di berbagai sektor saat ini masih belum memadai yang ditandai dengan masih banyaknya keluhan dan pengaduan dari masyarakat baik secara langsung maupun melalui media massa, hal ini terjadi juga di Puskesmas Gedong Tataan sebagai objek penelitian.

Berdasarkan uraian latar belakang masalah di atas, maka penulis tertarik untuk melakukan penelitian yang dituangkan dalam bentuk penelitian skripsi dengan judul "Pengaruh Stres dan Konflik Kerja Terhadap Kualitas Kerja Karyawan di Puskesmas Gedong Tataan”.

\section{Identifikasi Masalah}

1. Belum maksimalnya kualitas kerja pegawai Puskesmas Gedong Tataan dalam memberikan layanan kesehatan yang dibuktikan dengan masih adanya keluhan terhadap pelayanan Puskesmas dan masih tingginya angka kasus kematian bayi baru lahir (neonatal) dan balita di Kecamatan Gedong Tataan.
2. Munculnya tekanan (stres) akibat beban dan tuntutan pekerjaan yang relatif tinggi yaitu harapan masayarakat akan terselenggaranya layanan kesehatan yang baik dan maksimal oleh pegawai Puskesmas Gedong Tataan.

3. Konflik pekerjaan yang dialami pegawai Puskesmas yang sebagian besar adalah perempuan yang memiliki peran ganda sebagai ibu dalam mengurus keluarga..

\section{Rumusan Masalah}

1. Apakah stres berpengaruh terhadap kualitas kerja karyawan di Puskesmas Gedong Tataan?

2. Apakah konflik kerja berpengaruh terhadap kualitas kerja karyawan di Puskesmas Gedong Tataan?

3. Apakah stres dan konflik kerja berpengaruh terhadap kualitas kerja karyawan di Puskesmas Gedong Tataan ?

\section{TINJAUAN PUSTAKA, KERANGKA KONSEPTUAL DAN HIPOTESIS}

\section{Tinjauan Pustaka}

\section{Stres}

Menurut A.A. Anwar Prabu Mangkunegara (2011 : 157), stres adalah perasaan tertekan yang dialami karyawan dalam menghadapi pekerjaan. Stres kerja tampak dari gejala seperti emosi tidak stabil, perasaan tidak tenang, suka menyendiri, sulit tidur, tingkah laku yang berlebihan, tidak bisa rileks, cemas, tegang, gugup, tekanan darah meningkat bahkan dapat berimbas terhadap gangguan kesehatan.

Menurut Sondang P. Siagian (2014 : 300), stres merupakan kondisi ketegangan yang berpengaruh terhadap emosi, jalan pikiran dan kondisi fisik seseorang. Adapun menurut Manurung (2011 : 8), stres adalah suatu tanggapan dalam menyesuaikan diri 
yang dipengaruhi oleh perbedaan individu dan proses psikologis, sebagai konsekuensi dari tindakan lingkungan, situasi atau peristiwa yang terlalu banyak mengadakan tuntutan psikologis dan fisik seseorang.

Malayu SP. Hasibuan (2016 : 204) menyatakan bahwa, model stres kerja yang menjadi indikator stres kerja adalah sebagai berikut :

1. Beban kerja, diukur dari persepsi responden mengenai beban kerja yang dirasakan berlebihan.

2. Sikap pemimpin, diukur dari persepsi responden mengenai sikap pemimpin yang kurang adil dalam nenberikan tugas.

3. Waktu kerja, diukur dari persepsi responden mengenai waktu kerja yang dirasakan berlebihan.

4. Komunikasi, diukur dari persepsi responden mengenai komunikasi yang kurang baik antara karyawan.

5. Otoritas kerja, diukur dari persepsi responden mengenai otoritas kerja yang berhubugan dengan tanggung jawab.

\section{Konflik Kerja}

Menurut Veithzal Rivai (2011 : 999) "Konflik kerja adalah ketidaksesuaian antara dua atau lebih anggota-anggota atau kelompok (dalam suatu organisasi/ perusahaan) yang harus membagi sumber daya yang terbatas atau kegiatan-kegiatan kerja dan atau karena kenyataan bahwa mereka mempunyai perbedaan status, tujuan, nilai atau persepsi”.

Menurut A.A. Anwar Prabu Mangkunegara (2011 : 155) Sedangkan konflik kerja merupakan suatu situasi di mana terjadi adanya pertentangan antara dua atau lebih anggota organisasi atau kelompokkelompok dalam organisasi yang timbul karena adanya kegiatan bersama-sama yang mempunyai perbedaan status, tujuan, nilainilai, dan persepsi yang berbeda.
Menurut Fitriana (2013 : 192), indikator konflik kerja adalah sebagai berikut :

\section{a. Kesalahan komunikasi}

Apabila seseorang atau lebih menerima informasi yang berbeda atau tidak sama dengan sumber informasi sehingga terjadi perbedaan mendasar dalam mempersepsikan isi dari persepsi tersebut.

\section{b. Perbedaan tujuan}

Apabila seseorang atau lebih memiliki ketidaksamaan dalam memandang tujuan-tujuan yang hendak dicapai sehingga terjadi pertentangan dalam menyikapi tujuan-tujuan tersebut.

c. Perbedaan dalam penilaian atau persepsi

Perbedaan dalan penilaian antara anggota dalam suatu organisasi, seringkali disertai oleh perbedaanperbedaan dalam sikap, ketidaksesuaian nilai, persepsi, yang juga dapat menimbulkan konflik kerja.

\section{d. Interdependensi aktivitas kerja}

Terdapat adanya interdependensi kerja, apabila seseorang atau lebih saling tergantung satu sama lain dalam menyelesaikan tugas mereka masingmasing. Konflik akan terjadi apabila seseorang dari mereka diberi tugas secara berlebihan dan apabila salah seorang karyawan atau lebih harus menunggu atau menggantungkan pekerjaannya kepada karyawan lain.

\section{e. Kesalahan dalam afeksi}

Apabila seseorang memperlakukan rekan kerjanya menjadi tidak nyaman dalam bekerja, terutama dalam hal perasaan atau suasana hatinya.

\section{Pengertian Kualitas Kerja}

Menurut Laoshi Hao (2013 : 3), kualitas kerja adalah keandalan dalam pelaksanaan tugas sehingga terlaksana mutu yang tinggi, waktu yang tepat, cermat dan dengan prosedur yang mudah dipahami oleh pegawai yang mempunyai tanggung jawab 
besar terhadap tugas-tugas dan kewajiban yang diberikan, baik tanggung jawab pribadi, sosial, intelektual maupun tanggung jawab moral dan spiritual.

Kemudian menurut Edwin B. Flippo (2005 : 28), kualitas kerja adalah suatu hasil yang dapat diukur dengan efektifitas dan efisiensi suatu pekerjaan yang dilakukan oleh sumber daya manusia atau sumber daya lainnya dalam pencapaian tujuan atau sasaran perusahaan denga baik dan berdaya guna.

Kualitas kerja mengacu pada kualitas sumber daya manusia. Menurut Matutina (2011 : 205), kualitas sumber daya manusia mengacu pada :

a. Pengetahuan (Knowledge) yaitu kemampuan yang dimiliki karyawan yang lebih berorientasi pada intelejensi dan daya fikir serta penguasaan ilmu yang luas yang dimiliki karyawan.

b. Keterampilan (Skill), kemampuan dan penguasaan teknis operasional di bidang tertentu yang dimiliki karyawan.

c. Kemampuan (Abilities), yaitu kemampuan yang terbentuk dari sejumlah kompetensi yang dimiliki seorang karyawan yang mencakup loyalitas, kedisiplinan, kerja sama dan tanggung jawab.

Edwin B. Flippo (2005 : 91) kemudian menyatakan bahwa penting untuk menciptakan lingkungan untuk meningkatkan kualitas kerja, yaitu :

1) Tanggung jawab dan kepentingan pimpinan untuk menciptakan lingkungan peningkatan kualitas.

2) Nilai, sikap dan perilaku yang disetujui bersama diperlukan untuk meningkatkan mutu.

3) Sasaran peningkatan kualitas yang diterapkan oleh organisasi.

4) Komunikasi terbuka dan kerja sama tim baik.

5) Pengakuan dapat mendorong tindakan yang sesuai dengan nilai, sikap dan perilaku untuk meningkatkan mutu.
Selanjutnya indikator dari kualitas kerja pegawai menurut Malayu SP. Hasibuan (2016 : 95) antara lain :

1. Potensi diri, merupakan kemampuan, kekuatan, baik yang belum terwujud maupun yang telah terwujud, yang dimiliki seseorang tetapi belum sepenuhnya terlihat atau dipergunakan secara maksimal.

2. Hasil kerja optimal, harus dimiliki oleh seorang pegawai, pegawai harus bisa memberikan hasil kerjanya yang terbaik, salah satunya dapat dilihat dari produktivitas organisasi, kualitas kerja dan kuantitas kerja.

3. Proses kerja, merupakan suatu tahapan penting di mana pegawai menjalankan tugas dan perannya dalam suatu organisasi, melalui proses kerja ini kinerja pegawai dapat dilihat dari kemampuan membuat perencanaan kerja, kreatif dalam melaksanakan pekerjaan, mengevaluasi tindakan kerja, melakukan tindakan perbaikan.

4. Antusiasme, merupakan suatu sikap di mana seorang pegawai melakukan kepedulian terhadap pekerjaannya yang berhubungan dengan pelaksanaan pelayanan yaitu kehadiran, pelaksanaan tugas, motivasi kerja, komitmen kerja. Pegawai yang memiliki antusiasme akan senantiasa meningkatkan kinerjanya dalam menjalankan segala tugas dan tanggungjawabnya hal ini selalu ditumbuhkan dalam jiwa pegawai sebagai upaya untuk meningkatkan kualitas kinerjanya.

\section{Kerangka Konseptual}

Stres kerja dapat terjadi di dalam diri seorang karyawan, hal itu dikarenakan adanya tekanan yang terus menerus dari pekerjaan maupun hal-hal lain seperti tekanan dari atasan atau rekan kerja. Beban pekerjaan yang banyak tidak jarang akan menimbulkan stres kerja sehingga pekerjaan tidak akan selesai tepat waktu. Stres kerja 
yang terus menerus kemudian akan menurunkan gairah kerja karyawan sehingga produktifitas dan kualitas kerjanya menurun. Di samping itu adanya konflik yang terjadi dalam lingkungan pekerjaan merupakan salah satu pemicu sumber tekanan, karyawan yang saling tidak mempercayai rekannya, karyawan yang emosional, atau adanya sumber konflik dari luar lingkungan kerja akan membuat seorang karyawan menjadi tidak nyaman dalam melaksanakan pekerjaannya.

Jika antar karyawan tidak saling mendukung dalam pekerjaan maka

\section{Kerangka Pikir}

Paradigma Penelitian perusahaan tidak akan mencapai visi misi dan targetnya. Stres kerja yang disertai dengan konflik kerja menciptakan suasana yang tidak kondusif dan kualitas kerja menjadi tidak optimal. Dengan demikian stres dan konflik kerja berpengaruh negatif terhadap kualitas kerja karyawan.

Berdasarkan uraian konseptual sebagaimana tersebut di atas, selanjutnya dapat digambarkan paradigma penelitian sebagai berikut.

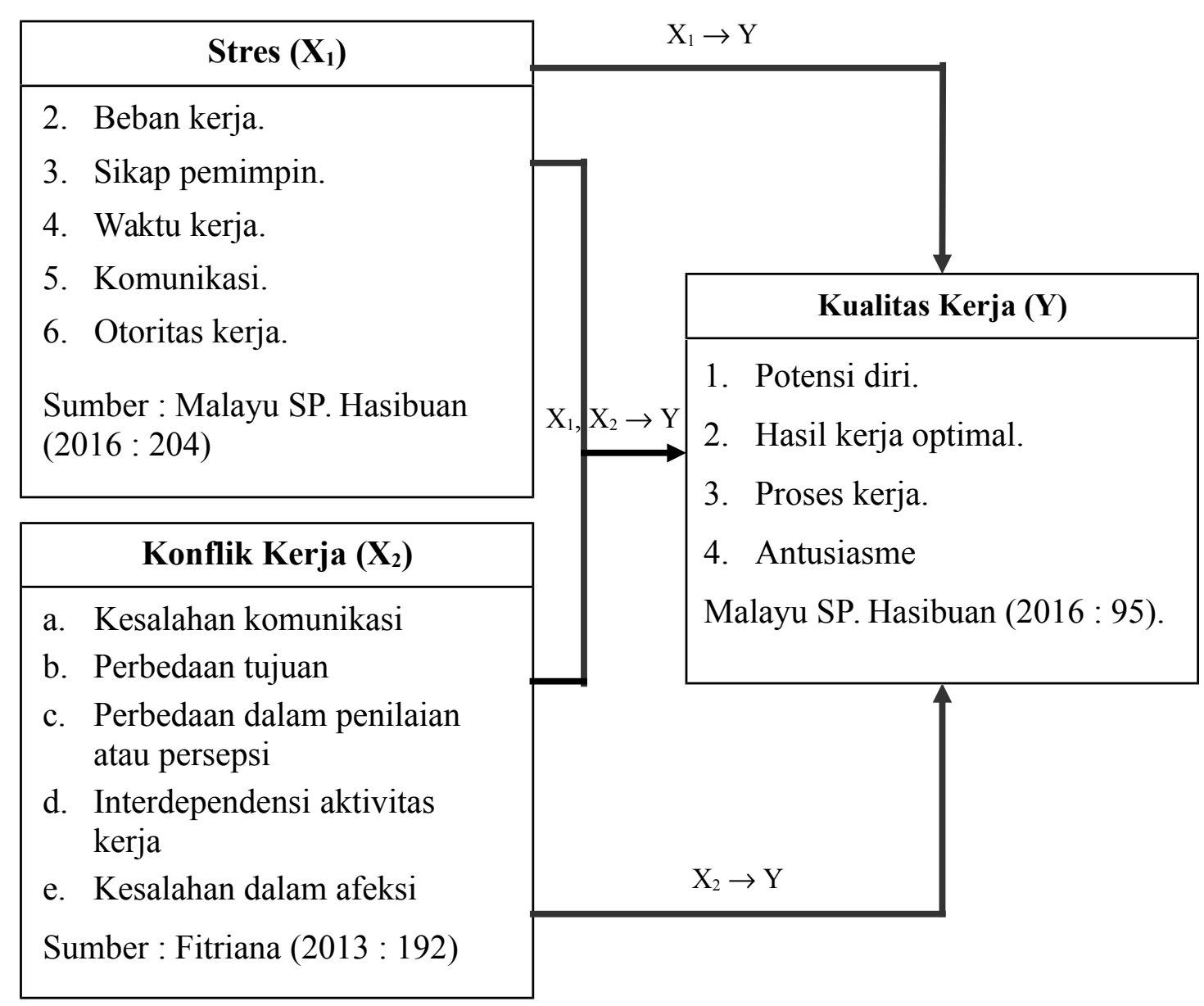

\section{Hipotesis}


Hipotesis yang diajukan dalam penelitian ini adalah :

1. Stres berpengaruh terhadap kualitas kerja karyawan di Puskesmas Gedong Tataan.

2. Konflik kerja berpengaruh terhadap kualitas kerja karyawan di Puskesmas Gedong Tataan.

3. Stres dan konflik kerja berpengaruh terhadap kualitas kerja karyawan di Puskesmas Gedong Tataan.

\section{METODE PENELITIAN}

\section{Jenis Penelitian}

jenis penelitian yang digunakan dalam penelitian ini adalah penelitian survei dengan pendekatan kuantitatif. Penelitian survei adalah penelitian yang dilakukan pada populasi besar maupun kecil, tetapi data yang dipelajari adalah data dari sampel yang diambil dari populasi tersebut, sehingga ditemukan kejadian-kejadian relatif, distribusi dan hubungan-hubungan antar variabel sosiologis maupun psikologis (Sugiyono, 207 : 7). Pendekatan survei dalam penelitian ini dilakukan dengan penyebaran kuisioner kepada individu sebagai responden.

Kemudian menurut Sugiyono (2017 : 8), penelitian kuantitatif adalah metode penelitian yang berlandaskan pada filsafat positivisme, digunakan untuk meneliti pada populasi atau sampel tertentu, pengumpulan data menggunakan instrumen penelitian, analisis data bersifat kuantitatif/statistik, dengan tujuan untuk menguji hipotesis yang telah ditetapkan.

\section{Variabel Penelitian}

Sesuai dengan judul penelitian ini, maka terdapat 3 (tiga) variabel yang diteliti yaitu :

1. Stres adalah perasaan tertekan yang dialami karyawan dalam menghadapi pekerjaan (A.A. Anwar Prabu Mangkunegara, 2011 : 157).

2. Konflik kerja adalah ketidaksesuaian antara dua atau lebih anggota-anggota atau kelompok (dalam suatu organisasi/perusahaan) yang harus membagi sumber daya yang terbatas atau kegiatan-kegiatan kerja dan atau karena kenyataan bahwa mereka mempunyai perbedaan status, tujuan, nilai atau persepsi (Veithzal Rivai, 2011 : 999).

3. Kualitas kerja adalah keandalan dalam pelaksanaan tugas sehingga terlaksana mutu yang tinggi, waktu yang tepat, cermat dan dengan prosedur yang mudah dipahami oleh pegawai yang mempunyai tanggung jawab besar terhadap tugas-tugas dan kewajiban yang diberikan, baik tanggung jawab pribadi, sosial, intelektual maupun tanggung jawab moral dan spiritual (Laoshi Hao, 2013 : 3).

\section{Populasi Penelitian}

Populasi adalah wilayah generalisasi yang terdiri atas obyek/subyek yang mempunyai kualitas dan karakteristik tertentu yang ditetapkan oleh peneliti untuk dipelajari dan kemudian ditarik kesimpulannya (Sugiyono, $2017: 80$ ).

Tabel 1. Data Pegawai Puskesmas Gedong Tataan

\begin{tabular}{|c|l|c|}
\hline No. & \multicolumn{1}{|c|}{ Fungsi } & $\begin{array}{c}\text { Jumlah } \\
\text { (Orang) }\end{array}$ \\
\hline 1. & Kepala Puskesmas & 1 \\
\hline 2. & Tenaga Medis & 4 \\
\hline 3. & Tenaga Bidan & 6 \\
\hline 4. & Tenga Perawat & 8 \\
\hline 5. & Tenaga Kefarmasian & 1 \\
\hline 6. & $\begin{array}{l}\text { Tenaga Kesehatan Masyarakat dan } \\
\text { Lingkungan }\end{array}$ & 1 \\
\hline 7. & Tenaga Gizi & 1 \\
\hline 8. & Tenaga Keteknisan Medis & 9 \\
\hline 9. & Tenaga Kesehatan Lain & 2 \\
\hline 10. & $\begin{array}{l}\text { Tenaga Penunjang/Pendukung } \\
\text { Kesehatan }\end{array}$ & $\mathbf{3 5}$ \\
\hline & \multicolumn{1}{|c|}{ Jumlah } & \\
\hline
\end{tabular}

Sumber : Puskesmas Gedong Tataan, 2019. 
Selanjutnya seluruh 35 populasi tersebut dijadikan sebagai responden penelitian, sehingga penelitian ini merupakan penelitian populasi.

\section{Teknik Pengumpulan Data}

1. Studi Kepustakaan (Library Research)

Dalam hal ini penulis memperoleh data melalui literatur-literatur dan tulisantulisan lain yang tentunya ada hubungan dengan permasalahan yang sedang diteliti.

2. Studi Lapangan (Field Research)

a. Observasi

Yaitu dengan mengadakan pengamatan secara langsung terhadap objek yang diteliti pada Puskesmas Gedong Tataan.

b. Wawancara

Yaitu dengan cara mengadakan tanya jawab langsung terhadap pihak-pihak yang terkait dalam penelitian ini.

c. Kuesioner

Yaitu dengan menyebarkan angket/ kuisioner yang berisikan pertanyaan terstruktur untuk mendapatkan informasi dari responden penelitian.

d. Dokumentasi

Yaitu suatu metode pengumpulan data melalui pencatatan terhadap laporan-laporan, arsip-arsip dan sebagainya.

\section{Metode Analisis}

\section{Analisis Kualitatif}

Analisis kualitatif dilakukan dengan mendeskriptifkan semua data dari seluruh variabel penelitian dalam bentuk distribusi frekuensi sehingga data-data yang diperoleh melalui kuesioner dapat disederhanakan ke dalam bentuk yang lebih mudah dibaca dan kemudian diinterpretasikan melalui pendekatan teori.

\section{Analisis Kuantitatif}

\section{Uji Regresi Linier Berganda}

Uji regresi linier mengestimasikan besarnya koefisien-koefisien yang dihasilkan dari persamaan yang bersifat linier, yang melibatkan beberapa variabel bebas, untuk digunakan sebagai alat prediksi. Untuk mengetahui pengaruh stres $\left(\mathrm{X}_{1}\right)$, konflik kerja $\left(\mathrm{X}_{2}\right)$ terhadap kualitas kerja $(\mathrm{Y})$ secara parsial dan simultan, rumus yang digunakan adalah sebagai berikut :

$\mathbf{Y}=\mathbf{a}+\mathbf{b}_{1} \mathbf{X}_{1}+\mathbf{b}_{2} \mathbf{X}_{2}+\mathbf{E t}$

Keterangan :

$$
\begin{aligned}
& \mathrm{Y}=\text { Variabel kualitas kerja } \\
& \mathrm{X}_{1}=\text { Variabel stres } \\
& \mathrm{X}_{2}=\text { Variabel konflik kerja } \\
& \mathrm{a}=\text { Intercept } \\
& \mathrm{b}=\text { Koefisien regresi } \\
& \mathrm{Et}=\text { error term }
\end{aligned}
$$

\section{Uji Koefisien Penentu (KP)}

Untuk mengetahui besarnya persentase pengaruh dari variabel bebas terhadap variabel terikat, digunakan rumus Koefisien Penentu (KP) atau Koefisien Determinasi sebagai berikut :

$$
K P=r^{2} X 100 \%
$$

\section{Uji Hipotesis}

Selanjutnya untuk menguji secara hipotesis secara parsial digunakan $\mathrm{Uji} \mathrm{t}$ dengan rumus, yaitu :

$$
\mathrm{t}_{\text {hitung }}=\frac{\mathrm{r} \sqrt{\mathrm{n}-2}}{\sqrt{1-\mathrm{r}^{2}}}
$$

Kemudian untuk menguji hipotesis secara keseluruhan (simultan) digunakan Uji F :

$$
\mathrm{F}_{\mathrm{hit}}=\frac{\mathrm{R}^{2}(\mathrm{n}-\mathrm{k}-1)}{\mathrm{k}\left(1-\mathrm{R}^{2}\right)}
$$




\section{HASIL PENELITIAN DAN PEMBAHASAN}

\section{Analisis Kualitatif}

Analisis kualitatif dalam pembahasan ini merupakan deskripsi data setiap variabel atau penjelasan tabel yang meliputi variabel-variabel yang diteliti yaitu variabel stres $\left(\mathrm{x}_{1}\right)$, konflik kerja $\left(\mathrm{x}_{2}\right)$ serta kualitas kerja (Y) sebagaimana dapat diuraikan berikut ini.

\section{a. Tanggapan Responden terhadap Variabel Stres}

Tabel 2. Tanggapan Responden terhadap Pertanyaan pada Variabel Stres

\begin{tabular}{|c|c|c|c|c|c|c|c|c|c|}
\hline \multirow{2}{*}{\multicolumn{2}{|c|}{ Pertanyaan }} & \multicolumn{5}{|c|}{ Kategori Jawaban } & \multirow{2}{*}{ Total } & \multirow{2}{*}{$\begin{array}{c}\text { Rata- } \\
\text { rata }\end{array}$} & \multirow{2}{*}{$\begin{array}{c}\text { Bobot } \\
\text { Nilai }\end{array}$} \\
\hline & & SS & $\mathbf{S}$ & CS & TS & STS & & & \\
\hline 1. & $\begin{array}{l}\text { Saya merasa terbebani dengan waktu yang } \\
\text { diberikan dalam menyelesaikan pekerjaan }\end{array}$ & 9 & 19 & 7 & 0 & 0 & 142 & 4,06 & $\begin{array}{l}\text { Sangat } \\
\text { Setuju }\end{array}$ \\
\hline 2. & $\begin{array}{l}\text { Tanggung jawab pekerjaan sebagai pelayan di } \\
\text { bidang jasa kesehatan terasa memberatkan }\end{array}$ & 7 & 17 & 11 & 0 & 0 & 136 & 3,89 & Setuju \\
\hline 3. & $\begin{array}{l}\text { Atasan memberikan memberikan bantuan } \\
\text { untuk pekerjaan yang memberatkan }\end{array}$ & 4 & 17 & 13 & 1 & 0 & 129 & 3,69 & Setuju \\
\hline 4. & $\begin{array}{l}\text { Atasan memberikan reward dan punishment } \\
\text { atas kinerja pegawai }\end{array}$ & 2 & 19 & 12 & 2 & 0 & 126 & 3,60 & Setuju \\
\hline 5. & $\begin{array}{l}\text { Waktu kerja dalam pelayanan kesehatan } \\
\text { membuat tekanan yang tinggi untuk } \\
\text { menyelesaikan setiap pekerjaan }\end{array}$ & 4 & 19 & 10 & 2 & 0 & 130 & 3,71 & Setuju \\
\hline 6. & $\begin{array}{l}\text { Sebagai pelayan di bidang kesehatan dengan } \\
\text { rutinitas yang tinggi, membuat saya kesulitas } \\
\text { membagi waktu dengan keluarga }\end{array}$ & 4 & 19 & 10 & 2 & 0 & 129 & 3,69 & Setuju \\
\hline 7. & $\begin{array}{l}\text { Pimpinan memberikan ruang komunkasi } \\
\text { kepada pegawai untuk kenyamanan dalam } \\
\text { bekerja }\end{array}$ & 4 & 22 & 9 & 0 & 0 & 135 & 3,86 & Setuju \\
\hline 8. & $\begin{array}{l}\text { Komunikasi dengan rekan kerja berjalan } \\
\text { dengan baik }\end{array}$ & 6 & 19 & 10 & 0 & 0 & 136 & 3,89 & Setuju \\
\hline 9. & $\begin{array}{l}\text { Tuntutan pekerjaan diimbangi dengan } \\
\text { ketersediaan fasilitas yang ada di Puskesmas }\end{array}$ & 4 & 26 & 5 & 0 & 0 & 139 & 3,97 & Setuju \\
\hline 10 & $\begin{array}{l}\text { Dalam pelaksanaan pekerjaan, terjadi } \\
\text { perbedaan persepsi antara pegawai dalam } \\
\text { menentukan penyebab masalah dan solusi } \\
\text { yang diberikan }\end{array}$ & 4 & 15 & 15 & 1 & 0 & 127 & 3,63 & Setuju \\
\hline & Jumlah & 48 & 191 & 103 & 8 & $\mathbf{0}$ & 1329 & 3,80 & Baik \\
\hline
\end{tabular}

Sumber : Data Diolah, 2020.

Berdasarkan jawaban responden di atas, dapat diketahui bahwa yang mendapat penilaian tertinggi oleh responden adalah pada pertanyaan pertama yaitu "Saya merasa terbebani dengan waktu yang diberikan dalam menyelesaikan pekerjaan" dengan rata-rata skor 4,06 atau termasuk sangat setuju. Adapun yang mendapat penilaian terendah adalah pada pertanyaan keempat yaitu "Atasan memberikan reward dan punishment atas kinerja pegawai", dengan rata-rata skor 3,60 atau termasuk setuju.

Berdasarkan hasil tersebut, karyawan meyakini bahwa pada variabel stres, yang paling menimbulkan stres adalah beban pekerjaan yang harus diselesaikan oleh karyawan/pegawai, sedangkan yang paling rendah yang mengakibatkan stres adalah adanya reward (penghargaan) dan punish (sanksi) atas kinerja masing-masing pegawai. 
Tabel 3. Tabel Distribusi Frekuensi Jawaban Responden pada Variabel Stres

\begin{tabular}{|c|l|c|c|}
\hline $\begin{array}{c}\text { No } \\
\cdot\end{array}$ & \multicolumn{1}{|c|}{$\begin{array}{c}\text { Interval Skor } \\
\text { Penilaian }\end{array}$} & $\begin{array}{c}\text { Jumlah } \\
\text { Jawaba } \\
\text { n }\end{array}$ & $\begin{array}{c}\text { Persentase } \\
(\%)\end{array}$ \\
\hline 1. & Sangat Setuju & 14 & 40,00 \\
\hline 2. & Setuju & 17 & 48,57 \\
\hline 3. & Cukup Setuju & 4 & 11,43 \\
\hline 4. & Tidak Setuju & 0 & 0,00 \\
\hline 5. & Sangat Tidak Setuju & 0 & 0,00 \\
\hline \multicolumn{2}{|r|}{ Jumlah } & $\mathbf{3 5}$ & $\mathbf{1 0 0}$ \\
\hline
\end{tabular}

Sumber : Data Diolah, 2020.

Berdasarkan jawaban di atas dapat diketahui bahwa jawaban paling banyak adalah pada kategori setuju yaitu sebanyak 17 orang responden (48,57\%), dengan demikian dapat disimpulkan bahwa sebagian responden menyatakan setuju terhadap item pertanyaan yang diajukan pada variabel stres.

\section{b. Tanggapan Responden Terhadap Variabel Konflik Kerja}

Tabel 4. Tanggapan Responden Pertanyaan Variabel Konflik Kerja

\begin{tabular}{|c|c|c|c|c|c|c|c|c|c|}
\hline \multirow{2}{*}{\multicolumn{2}{|c|}{ Pertanyaan }} & \multicolumn{5}{|c|}{ Kategori Jawaban } & \multirow[b]{2}{*}{ Total } & \multirow{2}{*}{$\begin{array}{l}\text { Rata- } \\
\text { rata }\end{array}$} & \multirow{2}{*}{$\begin{array}{c}\text { Bobot } \\
\text { Nilai }\end{array}$} \\
\hline & & SS & $\mathbf{S}$ & $\mathrm{CS}$ & TS & STS & & & \\
\hline 1. & $\begin{array}{l}\text { Dalam bekerja terkadang saya } \\
\text { mengalami percekcokan atau } \\
\text { perdebatan dengan rekan kerja }\end{array}$ & 7 & 17 & 11 & 0 & 0 & 136 & 3,89 & Setuju \\
\hline 2. & $\begin{array}{l}\text { Komunikasi kerja antara saya dan } \\
\text { rekan kerja sudah berjalan baik }\end{array}$ & 7 & 20 & 7 & 1 & 0 & 138 & 3,94 & Setuju \\
\hline 3. & $\begin{array}{l}\text { Saya dan rekan kerja saya sering } \\
\text { mengalami perbedaan visi dalam } \\
\text { menyelesaiakan pekerjaan }\end{array}$ & 9 & 18 & 8 & 0 & 0 & 141 & 4,03 & $\begin{array}{l}\text { Sangat } \\
\text { Setuju }\end{array}$ \\
\hline 4. & $\begin{array}{l}\text { Terkadang rekan kerja saya dalam } \\
\text { pelaksanaan pekerjaan tidak sesuai } \\
\text { dengan visi yang rancang }\end{array}$ & 12 & 15 & 8 & 0 & 0 & 144 & 4,11 & $\begin{array}{l}\text { Sangat } \\
\text { Setuju }\end{array}$ \\
\hline 5. & $\begin{array}{l}\text { Perbedaan pendapat sering terjadi } \\
\text { dengan rekan kerja dalam menilai } \\
\text { pekerjaan yang ada }\end{array}$ & 13 & 17 & 5 & 0 & 0 & 148 & 4,23 & $\begin{array}{l}\text { Sangat } \\
\text { Setuju }\end{array}$ \\
\hline 6. & $\begin{array}{l}\text { Ada perbedaan sudut pandang antara } \\
\text { saya dan rekan kerja dalam melihat } \\
\text { akar permasalahan dalam bekerja }\end{array}$ & 5 & 18 & 11 & 1 & 0 & 132 & 3,77 & Setuju \\
\hline 7. & $\begin{array}{l}\text { Setiap pegawai membutuhkan } \\
\text { bantuan dari rekan kerja dalam } \\
\text { pelaksanaan pekerjaan }\end{array}$ & 4 & 18 & $12^{\prime}$ & 1 & 0 & 130 & 3,71 & Setuju \\
\hline 8. & $\begin{array}{l}\text { Masih ada rekan kerja yang kerap } \\
\text { kurang menguasai bidang } \\
\text { pekerjaannya }\end{array}$ & 4 & 14 & 15 & 2 & 0 & 125 & 3,57 & Setuju \\
\hline 9. & $\begin{array}{l}\text { Saya mengalami konflik emosional } \\
\text { dengan rekan kerja ketika terjadi } \\
\text { perbedaan penyelesaian pekerjaan }\end{array}$ & 10 & 14 & 10 & 1 & 0 & 138 & 3,94 & Setuju \\
\hline 10. & $\begin{array}{l}\text { Ketegangan dalam bekerja sering } \\
\text { terjadi dengan rekan kerja ketika } \\
\text { terjadi kesalahan kecil }\end{array}$ & 7 & 16 & 12 & 0 & 0 & 135 & 3,86 & Setuju \\
\hline & Jumlah Total & 78 & 167 & 99 & 6 & $\mathbf{0}$ & 1367 & 3,91 & Setuju \\
\hline
\end{tabular}

Sumber : Data Diolah, 2020. 
Berdasarkan jawaban responden di atas, dapat diketahui bahwa yang mendapat penilaian tertinggi oleh responden adalah pada pertanyaan kelima yaitu "Perbedaan pendapat sering terjadi dengan rekan kerja dalam menilai pekerjaan yang ada" dengan rata-rata skor 4,23 atau termasuk sangat setuju. Adapun yang mendapat penilaian terendah adalah pada pertanyaan kedelapan yaitu "Masih ada rekan kerja yang kerap kurang menguasai bidang pekerjaannya", dengan rata-rata skor 3,57 yang termasuk kategori setuju.

Berdasarkan hal tersebut di atas dapat diketahui bahwa karyawan meyakini bahwa pada variabel konflik kerja, yang paling kerap kali terjadi konflik adalah akibat adanya perbedaan pendapat dengan rekan kerja dalam menilai pekerjaan yang ada. Sedangkan yang paling kurang menimbulkan konflik kerja adalah rekan kerja yang kurang menguasai bidang pekerjaannya.

Tabel 5. Tabel Distribusi Frekuensi Jawaban Responden Variabel Konflik Kerja

\begin{tabular}{|c|l|c|c|}
\hline $\begin{array}{c}\text { No } \\
\cdot\end{array}$ & \multicolumn{1}{|c|}{$\begin{array}{c}\text { Interval Skor } \\
\text { Penilaian }\end{array}$} & $\begin{array}{c}\text { Jumlah } \\
\text { Jawaba } \\
\mathbf{n}\end{array}$ & $\begin{array}{c}\text { Persentase } \\
\mathbf{( \% )}\end{array}$ \\
\hline 1. & Sangat Setuju & 13 & 37,14 \\
\hline 2. & Setuju & 13 & 37,14 \\
\hline 3. & Cukup Setuju & 9 & 25,71 \\
\hline 4. & Tidak Setuju & 0 & 0,00 \\
\hline 5. & Sangat Tidak Setuju & 0 & 0,00 \\
\hline \multicolumn{2}{|c|}{ Jumlah } & $\mathbf{3 5}$ & $\mathbf{1 0 0 , 0 0}$ \\
\hline
\end{tabular}

Sumber : Data Diolah, 2020.

Berdasarkan jawaban di atas dapat diketahui bahwa jawaban paling banyak adalah pada kategori setuju dan sangat setuju yaitu masing-masing sebanyak 13 orang responden $(37,14 \%)$, sedangkan yang menjawab cukup setuju adalah sebanyak 9 responden $(25,71 \%)$.

\section{c. Tanggapan Responden Terhadap Variabel Kualitas Kerja}

Tabel 6. Tanggapan Responden terhadap Variabel Kualitas Kerja

\begin{tabular}{|c|c|c|c|c|c|c|c|c|c|}
\hline \multirow{2}{*}{\multicolumn{2}{|c|}{ Pertanyaan }} & \multicolumn{5}{|c|}{ Kategori Jawaban } & \multirow[b]{2}{*}{ Total } & \multirow{2}{*}{$\begin{array}{c}\text { Rata- } \\
\text { rata }\end{array}$} & \multirow{2}{*}{$\begin{array}{l}\text { Bobot } \\
\text { Nilai }\end{array}$} \\
\hline & & SS & $\mathbf{S}$ & $\mathrm{CS}$ & TS & STS & & & \\
\hline 1. & $\begin{array}{l}\text { Saya mampu mencapai standar kerja } \\
\text { (personal) yang telah ditetapkan }\end{array}$ & 10 & 18 & 7 & 0 & 0 & 143 & 4,09 & $\begin{array}{l}\text { Sangat } \\
\text { Setuju }\end{array}$ \\
\hline 2. & $\begin{array}{l}\text { Saya berusaha untuk berkerja maksimal } \\
\text { setiap waktu }\end{array}$ & 12 & 16 & 7 & 0 & 0 & 145 & 4,14 & $\begin{array}{l}\text { Sangat } \\
\text { Setuju }\end{array}$ \\
\hline 3. & $\begin{array}{l}\text { Saya yakin dengan kemampuan saya dalam } \\
\text { memberikan pelayanan kesehatan kepada } \\
\text { masyarakat di Puskesmas }\end{array}$ & 4 & 22 & 9 & 0 & 0 & 135 & 3,86 & Setuju \\
\hline 4. & $\begin{array}{l}\text { Saya dapat menyelesaikan pekerjaan } \\
\text { dengan tingkat ketelitian yang tinggi }\end{array}$ & 6 & 21 & 6 & 2 & 0 & 136 & 3,89 & Setuju \\
\hline 5. & $\begin{array}{l}\text { Hasil kerja saya menunjukkan peningkatan } \\
\text { dari waktu ke waktu }\end{array}$ & 3 & 18 & 13 & 1 & 0 & 128 & 3,66 & Setuju \\
\hline 6. & $\begin{array}{l}\text { Saya siap menerima kritikan dari semua } \\
\text { pihak demi perbaikan pekerjaan yang } \\
\text { menjadi tanggung jawab saya }\end{array}$ & 7 & 21 & 7 & 0 & 0 & 140 & 4,00 & Setuju \\
\hline 7. & $\begin{array}{l}\text { Saya dapat menyelesaikan pekerjaan saya } \\
\text { dengan tepat waktu }\end{array}$ & 4 & 21 & 10 & 0 & 0 & 134 & 3,83 & Setuju \\
\hline 8. & $\begin{array}{l}\text { Tekanan dalam pekerjaan membuat saya } \\
\text { lebih termotivasi untuk memberikan } \\
\text { pelayanan yang maksimal kepada } \\
\text { masyarakat }\end{array}$ & 8 & 23 & 4 & 0 & 0 & 144 & 4,11 & $\begin{array}{l}\text { Sangat } \\
\text { Setuju }\end{array}$ \\
\hline 9. & $\begin{array}{l}\text { Tanggung jawab pekerjaan yang diberikan } \\
\text { dapat saya laksanakan dengan baik }\end{array}$ & 7 & 18 & 9 & 1 & 0 & 136 & 3,89 & Setuju \\
\hline 10 & Saya senang memberikan pelayanan & 7 & 21 & 7 & 0 & 0 & 140 & 4,00 & Setuju \\
\hline
\end{tabular}




\begin{tabular}{|c|l|c|c|c|c|c|c|c|c|}
\hline$\cdot$ & $\begin{array}{l}\text { kesehatan kepada masyarakat yang } \\
\text { membutuhkan }\end{array}$ & & & & & & & & \\
\hline Total Jumlah & $\mathbf{6 8}$ & $\mathbf{1 9 9}$ & $\mathbf{7 9}$ & $\mathbf{4}$ & $\mathbf{0}$ & $\mathbf{1 3 8 1}$ & $\mathbf{3 , 9 5}$ & Setuju \\
\hline
\end{tabular}

Sumber : Data Diolah, 2020.

Berdasarkan jawaban responden pada variabel kualitas kerja, dapat diketahui bahwa yang mendapat penilaian tertinggi oleh responden adalah pada pertanyaan kedua yaitu "Saya berusaha untuk berkerja maksimal setiap waktu" dengan rata-rata skor 4,14 atau termasuk sangat setuju. Adapun yang mendapat penilaian terendah adalah pada pertanyaan kelima yaitu "Hasil kerja saya menunjukkan peningkatan dari waktu ke waktu", dengan rata-rata skor 3,66 atau termasuk setuju.

Berdasarkan hal tersebut di atas dapat diketahui bahwa pada variabel kualitas kerja yang paling disetujui oleh karyawan adalah bahwa mereka telah berusaha untuk berkerja maksimal setiap waktu, sedangkan yang paling rendah mendapat penilaian oleh karyawan adalah hasil kerja menunjukkan peningkatan dari waktu ke waktu.

Tabel 7. Tabel Distribusi Frekuensi Jawaban Responden pada Variabel Kualitas Kerja

\begin{tabular}{|c|l|c|c|}
\hline No. & $\begin{array}{c}\text { Interval Skor } \\
\text { Penilaian }\end{array}$ & $\begin{array}{c}\text { Jumlah } \\
\text { Jawaban }\end{array}$ & $\begin{array}{c}\text { Persentase } \\
(\mathbf{\%})\end{array}$ \\
\hline 1. & Sangat Setuju & 14 & 40,00 \\
\hline 2. & Setuju & 17 & 48,57 \\
\hline 3. & Cukup Setuju & 4 & 11,43 \\
\hline 4. & Tidak Setuju & 0 & 0,00 \\
\hline 5. & $\begin{array}{l}\text { Sangat Tidak } \\
\text { Setuju }\end{array}$ & 0 & 0,00 \\
\hline \multicolumn{2}{|l}{ Jumlah } & $\mathbf{3 5}$ & $\mathbf{1 0 0 , 0 0}$ \\
\hline
\end{tabular}

Sumber : Data Diolah, 2020.

Berdasarkan jawaban di atas dapat diketahui bahwa jawaban paling banyak adalah pada kategori setuju yaitu sebanyak 17 orang responden $(48,67 \%)$, dengan demikian dapat disimpulkan bahwa sebagian responden setuju terhadap pertanyaan yang diajukan pada variabel kualitas kerja.
Selanjutnya untuk menguji hipotesis dan mengetahui pengaruh variabel Stres terhadap kualitas kerja, pengaruh variabel konflik kerja terhadap kualitas kerja serta pengaruh stres dan konflik kerja terhadap kualitas kerja dilakukan analisis kuantitatif menggunakan rumus regresi berganda sebagai berikut.

\section{a. Uji Regresi Linear Berganda}

\section{1) Pengaruh Stres terhadap Kualitas Kerja}

Analisis regresi menghasilkan arah regresi b sebesar 0,340 dan konstanta a sebesar 9,213 . Dengan demikian pengaruh stres terhadap kualitas kerja dapat digambarkan melalui persamaan regresi : $\hat{\mathbf{Y}}=\mathbf{7 , 6 1 4}+$ $\mathbf{0 , 3 4 0} \mathrm{X}_{\mathbf{1}}$.

\section{2) Pengaruh Konflik Kerja terhadap Kualitas Kerja}

Analisis regresi menghasilkan arah regresi $b$ sebesar 0,485 dan konstanta a sebesar 7,614. Dengan demikian pengaruh konflik kerja terhadap kualitas kerja dapat digambarkan melalui persamaan regresi : $\hat{\mathbf{Y}}=\mathbf{7 , 6 1 4}+\mathbf{0 , 4 8 5} \mathrm{X}_{2}$.

\section{3) Pengaruh Stres dan Konflik kerja terhadap Kualitas kerja}

Secara simultan pengaruh Stres dan Konflik kerja terhadap Kualitas kerja (Y) dapat digambarkan melalui persamaan regresi : $\hat{\mathbf{Y}}=\mathbf{7 , 6 1 4}+\mathbf{0 , 3 4 0} \mathrm{X}_{1}+\mathbf{0 , 4 8 5} \mathrm{X}_{2}$.

\section{b. Uji Koefisien Penentu/Koefisien Determinan}
1) Pengaruh Stres terhadap Kualitas Kerja

\section{Analisis Kuantitatif}


Berdasarkan hasil perhitungan Uji Koefisien Penentu dapat diketahui nilai $\mathrm{R}$ adalah sebesar 0,491, sehingga secara parsial korelasi variabel Stres terhadap variabel kualitas kerja termasuk kategori sedang. Nilai $\mathrm{R}^{2}$ (square) sebesar 0,241, artinya pengaruh Stres terhadap kualitas kerja sebesar $24,1 \%$, sisanya sebesar $75,9 \%$ dipengaruhi oleh variabel lain.

\section{2) Pengaruh Konflik Kerja terhadap Kualitas Kerja}

Berdasarkan hasil perhitungan Uji Koefisien Penentu dapat diketahui nilai $\mathrm{R}$ 0,643 , sehingga secara parsial korelasi konflik kerja terhadap kualitas kerja termasuk kategori tinggi. Nilai $\mathrm{R}^{2}$ (square) sebesar 0,433, artinya pengaruh konflik kerja terhadap variabel kualitas kerja sebesar $41,3 \%$, sedangkan sisanya sebesar $58,7 \%$ dipengaruhi oleh variabel lain.

\section{3) Pengaruh Stres dan Konflik Kerja terhadap Kualitas Kerja}

Berdasarkan hasil perhitungan nilai $\mathrm{R}$ 0,680, sehingga secara simultan pengaruh stres dan konflik kerja terhadap kualitas kerja termasuk kategori tinggi. Nilai $\mathrm{R}^{2}$ (square) sebesar 0,463, artinya pengaruh stres dan konflik kerja terhadap kualitas kerja sebesar $46,3 \%$, sisanya sebesar $53,7 \%$ dipengaruhi oleh variabel lain.

\section{c. Uji Hipotesis}

\section{1) Uji Hipotesis Stres terhadap Kualitas kerja}

Hipotesis pertama yang diajukan dalam penelitian ini adalah bahwa "Stres berpengaruh terhadap kualitas kerja karyawan di Puskesmas Gedong Tataan”.

Hasil uji $\mathrm{t}_{\text {hitung }}$ diperoleh nilai sebesar 2,177, sedangkan nilai $t_{\text {tabel }}$ untuk $\mathrm{n}=35$ pada $\alpha=$ 0,05 adalah 2,031. Dengan demikian nilai $t_{\text {hitung }}>\mathrm{t}_{\text {tabel }}$ (tolak Ho, terima Ha), hasil tersebut menunjukkan bahwa benar "Stres berpengaruh terhadap kualitas kerja karyawan di Puskesmas Gedong Tataan".

\section{2) Uji Hipotesis Konflik kerja terhadap Kualitas kerja}

Hipotesis kedua yang diajukan dalam penelitian ini menyatakan bahwa "Konflik kerja berpengaruh terhadap kualitas kerja karyawan di Puskesmas Gedong Tataan".

Hasil uji $t_{\text {hitung }}$ diperoleh nilai sebesar 3,639, sedangkan nilai $\mathrm{t}_{\text {tabel }}$ untuk $\mathrm{n}=35$ pada $\alpha=$ 0,05 adalah 2,031. Dengan demikian nilai $t_{\text {hitung }}>\mathrm{t}_{\text {tabel }}$ (tolak Ho, terima Ha), artinya hasil tersebut menunjukkan bahwa benar "Konflik kerja berpengaruh terhadap kualitas kerja karyawan di Puskesmas Gedong Tataan".

\section{Uji Hipotesis Simultan Stres dan Konflik Kerja terhadap Kualitas Kerja}

Hipotesis ketiga yang diajukan dalam penelitian ini adalah "Stres dan konflik kerja berpengaruh terhadap kualitas kerja karyawan di Puskesmas Gedong Tataan".

Hasil uji hipotesis simultan menggunakan Uji $F$, diperoleh nilai $F_{\text {hitung }}$ sebesar 13,794, sedangkan $\mathrm{F}_{\text {tabel }}$ pada pada taraf nyata $\mathrm{n}=$ 35, diperoleh nilai $\mathrm{F}_{\text {tabel }}=4,12$. Dengan demikian nilai $F_{\text {hitung }}>F_{\text {tabel }}$ (tolak Ho, terima $\mathrm{Ha}$ ) sehingga hasil ini membuktikan bahwa benar "Stres dan konflik kerja berpengaruh terhadap kualitas kerja karyawan di Puskesmas Gedong Tataan”.

\section{KESIMPULAN DAN SARAN}

\section{A. Simpulan}

Hasil penelitian menyimpulan bahwa : 
a. Stres $\left(\mathrm{X}_{1}\right)$ berpengaruh terhadap kualitas kerja karyawan (Y) di Puskesmas Gedong Tataan.

b. Konflik kerja $\left(\mathrm{X}_{2}\right)$ berpengaruh terhadap kualitas kerja karyawan (Y) di Puskesmas Gedong Tataan.

c. Stres $\left(X_{1}\right)$ dan konflik kerja $\left(X_{2}\right)$ berpengaruh terhadap kualitas kerja karyawan (Y) di Puskesmas Gedong Tataan.

\section{B. Saran}

Saran yang dapat dikemukakan adalah sebagaimana berikut :

1. Pada variabel stres, hendaknya Kepala Puskemas Gedong Tataan lebih dapat mengatur pembagian kerja individu dan tim sehingga beban pekerjaan yang harus diselesaikan dapat diselesaikan tanpa membebani setiap pegawai di Puskemas Gedong Tataan.

2. Pada variabel konflik kerja, hendaknya setiap pegawai mampu mengatasi perbedaan pendapat dengan rekan kerja dalam menilai pekerjaan sehingga perbedaan pendapat tersebut tidak menimbulkan konflik kerja yang berlebihan di Puskemas Gedong Tataan.

3. Pada variabel kualitas kerja, hendaknya seluruh pegawai di Puskesmas Gedong Tataan mampu mempertahankan upaya yang telah dilakukan dalam pelaksanaan pekerjaan setiap waktu sehingga dapat memberikan pelayanan kesehatan kepada masyarakat Kecamatan Gedong Tataan secara maksimal.

\section{DAFTAR PUSTAKA}

Danang Sunyoto, 2009, Analisis Regresi dan Uji Hipotesis, Medpress, Yogyakarta.

Malayu SP. Hasibuan, 2016, Manajemen Sumber Daya Manusia, PT. Bumi Aksara, Jakarta.
Manurung, 2011, Terapi Reminiscence, Solusi Pendekatan Sebagai Upaya Tindakan Keperawatan dalam Menurunkan Kecemasan Stres dan Depresi, Trans Info Media, Jakarta.

Freddy Rangkuti, 2007, Mengukur Efektivitas Program Promosi \& Analisis Kasus Menggunakan SPSS, Gramedia Pustaka Utama, Jakarta

Riduwan, 2009, Metode dan Teknik Menyusun Tesis, Penerbit Alfabeta, Bandung.

Sofyan Assauri, 2003, Manajemen Pemasaran: Konsep, Dasar, Strategi, Cetakan Ketujuh, PT. Grasindo Persada, Jakarta.

Sondang P. Siagian, 2014, Manajemen Sumber Daya Manusia, Bumi Aksara, Jakarta.

Sugiyono, 2017, Metode Penelitian Bisnis, CV. Alfabeta, Bandung.

Suharsimi Arikunto, 2012, Prosedur Penelitian Suatu Pendekatan Praktek, Rineka Cipta, Jakarta.

T. Hani Handoko, 2011, Manajemen Sumber Daya Manusia, Penerbit BPFE, Yogyakarta.

A.A. Anwar Mangkunegara, 2011, Manajemen Sumber Daya Manusia Perusahaan. PT. Remaja Rosdakarya, Bandung.

Edwin B. Flippo, 2005, Personel Management (Manajemen Personalia), Edisi. VII Jilid II, Terjemahan Alponso S, Erlangga, Jakarta.

Edy Sutrisno, 2012, Manajemen Sumber Daya Manusia. Edisi Pertama, 
Kencana Prenada Media Group, Jakarta.

Fitriana, 2013, Persepsi Insentif dengan Konflik Kerja Karyawan Perusahaan Roti Salwa Trenggalek, Jurnal Psikologi, Vol. 01 No. 1, Jakarta.

Gary Dessler, 2015, Manajemen Sumber Daya Manusia, Salemba Empat, Jakarta.

Hadari Nawawi, 2010, Manajemen Sumber Daya Manusia Untuk Bisnis, Ghalia Indonesia, Jakarta.

Laoshi Hao, 2013, Pelaksanaan Reformasi Birokrasi Dalam Meningkatkan Kualitas Kerja Pegawai, Jurnal Ekonomi dan Bisnis, Banjar.

Matutina, 2011, Manajemen Sumber Daya Manusia, Gramedia Widia Sarana, Jakarta.

Veithzal Rivai, 2011, Manajemen Sumber Daya Manusia Untuk Perusahaan Dari Teori Ke Praktik, PT. RajaGrafinfo Persada, Jakarta.

Wahyudi dan Akdon, 2005, Manajemen Konflik dalam Organisasi, Alfabeta, Bandung.

https://www.kupastuntas.co/2018/10/23/mas yarakat-keluhkan-pelayananpuskesmas-gedongtataan/. 